\title{
Modeling and Control Strategy for Multiterminal Flexible DC Distribution Network with Echelon Utilization Power Battery
}

\author{
Min Mou $\mathbb{D}^{1},{ }^{1}$ Yuhao Zhou, ${ }^{1}$ Wenguang Zheng, ${ }^{1}$ Yurong Xie, ${ }^{1}$ Shipeng Wang, ${ }^{1}$ Lili Liu, ${ }^{1}$ \\ and Chengzhi Wei ${ }^{2}$ \\ ${ }^{1}$ Huadian Electric Power Research Institute Co, Ltd, Hangzhou 310000, Zhejiang, China \\ ${ }^{2}$ Electric Power Research Institute of CSG, Guangzhou 510080, Guangdong, China \\ Correspondence should be addressed to Min Mou; min-mou@chder.com
}

Received 8 June 2021; Revised 2 July 2021; Accepted 17 July 2021; Published 27 July 2021

Academic Editor: Xiaoqing Bai

Copyright (c) 2021 Min Mou et al. This is an open access article distributed under the Creative Commons Attribution License, which permits unrestricted use, distribution, and reproduction in any medium, provided the original work is properly cited.

\begin{abstract}
With the integration of distributed renewable energy to the distribution network and the development of multiterminal flexible DC transmission technology, multiterminal flexible DC distribution network has broad application prospects. At the same time, with the rapid development of new energy vehicles, the echelon utilization of power battery has become a research hotspot. By analyzing the characteristics of flexible DC distribution network and echelon utilization battery, the structure and control strategy of modular multilevel converter (MMC), DC solid-state transformer, photovoltaic power generation, wind power generation, and echelon utilization battery energy storage system are established, respectively, in this paper. To achieve a DC network connection of various types of power supply and load, this paper proposes a starting method of multiterminal flexible DC distribution network and a cooperative control strategy of the wind-solar-storage system. A six-terminal ring-shape DC distribution network model is built in real-time digital simulation (RTDS) platform. The simulation results show that the modeling methods and control strategies of each component in the real-time simulation model meet the operation requirements of the multiterminal flexible DC distribution network, which provides a reference for the construction and research of the flexible DC distribution network.
\end{abstract}

\section{Introduction}

With the development of renewable energy technology and energy storage technology, modern distribution network will contain more and more distributed power and energy storage. The common distributed power sources include photovoltaic cells, fuel cells, wind turbines, and gas turbines, and the power generated by these power sources is DC or can be converted into DC after simple rectification. At the same time, the modern load situation has changed. More and more loads need to use DC power supply mode, such as LCD TV, LED lighting, electric vehicle, personal computer, and mobile phone; the development of DC power grid can greatly reduce the flow change link, reduce the load access cost, improve the power conversion efficiency and power quality, improve the energy utilization efficiency, and fully demonstrate the economic benefits and utilization value of distributed energy. With the increase in new energy generation rate, DC distribution will play an increasingly important role in the future power grid [1].

At present, the research on the flexible DC distribution network system is in the experimental exploration stage at home and abroad $[2,3]$. For the simulation design of DC distribution network, the paper [4] based on the demonstration project of Shenzhen MMC-DCDS proposes the starting and control strategy for the flexible DC distribution network, which is based on the system operation characteristics. The document [5] proposes the protection control system design scheme and corresponding control protection strategy of the converter station in the DC distribution network, but neither of them involves the research of the control strategy of the distributed power supply. The paper [6] studies the control and protection strategy of DC distribution network and builds the offline simulation model of the flexible DC distribution system based on MATLAB, which is used to verify the correctness of control strategy and the 
reliability of protection scheme, but offline simulation is not suitable for simulating high switching frequency power electronic devices. The papers [2,7] study and analyze the modeling and real-time simulation technology of the flexible DC distribution network with multiterminal, in which the real-time simulation model of DC distribution network based on the real-time Lab (RT-Lab) is established. The above research studies that involve the modeling of key equipment of the DC distribution system with wind-solar-storage and the coordination control strategy of the system are relatively few.

Based on the analysis of the key equipment of DC distribution network (including distributed generation, DC transformer, converter, and other components), this paper establishes a variety of load types of DC distribution network, such as modular multilevel converter, echelon utilization battery storage system, wind power generation device, photovoltaic power generation device, and synchronous motor, which are based on the control modes of vdc-q, P-Q, VF, and so on, so as to realize the DC network of multiple types of power supply and load. Based on the RTDS simulation platform, a six-terminal "ring" DC distribution network model is built to study the start-up and multisource coordinated control strategy of multiterminal DC distribution network. Finally, the simulation validation is carried out.

\section{Modeling of Components in Flexible DC Distribution System}

The multiterminal flexible DC distribution system is mainly composed of converter, DC transformer, distributed power supply (such as photovoltaic power generation system, wind power generation system, and energy storage device), and DC load.

2.1. Modular Multilevel Converter. At present, there are three kinds of voltage source converters used in flexible DC transmission projects: two-level voltage source converter (VSC), three-level VSC, and modular multilevel converter (MMC) [8]. MMC converter has the advantages of easy expansion, small harmonic distortion, low switching loss, no commutation failure, and strong fault handling ability [9-12]. It has been widely used in recent years.

The main circuit topology of three-phase MMC is shown in Figure 1(a). Each phase contains two arms of upper and lower bridge, and there are six bridge arms in all three phases. Each bridge arm is composed of $\mathrm{N}$ submodules (SM) and a circulation reactor in series. The structure of SM is shown in Figure 1(b), which consists of a half bridge with switching element IGBT and a DC energy storage capacitor.

MMC modeling is mainly divided into three modules: MMC control module, valve module, and main circuit. The MMC control module is mainly responsible for the active and reactive power control of the converter and then outputs the voltage amplitude and phase of the modulated wave corresponding to the power instruction value $[13,14]$. The valve module uses the number of submodule corresponding to the former modulation waveform to control the state of each submodule by a set of optimization algorithm so as to realize commutation. In addition, the control of MMC converter also includes some auxiliary control, such as startup, phase-locked, internal circulation suppression, and negative sequence voltage suppression. The control strategy structure of MMC is shown in Figure 2.

2.2. DC Solid-State Transformer. DC solid-state transformer (DCSST) based on power electronics technology can realize the matching of different voltage levels in DC distribution network. In order to improve the power density, a dualactive-bridge (DAB) structure can be used for the applications requiring bidirectional power transmission. DCSST is mainly composed of $\mathrm{N}$ identical $\mathrm{DAB}$ converters; each DAB converter consists of two full Bridges and one highfrequency isolation transformer, as shown in Figure 3. N $\mathrm{DAB}$ converters are connected in series at the high voltage end to connect with the high voltage DC bus and connected in parallel at the low voltage end to connect with the low voltage DC bus so as to increase the voltage level of the high voltage side by $n$ times and the current level of the low voltage end by $n$ times.

DAB in DCSST is controlled by phase shift, and energy transmission is realized by the size of phase shift between two cell bridges. The control block diagram of DAB with constant voltage and low voltage is shown in Figure 4. Among them, $\mathrm{V}_{\text {sec }}^{*}$ and $\mathrm{V}_{\text {sec }}$ represent the standard and measured values of the DC voltage on the secondary side of DAB, respectively; $\delta_{1}$ represents the voltage phase angle at the midpoint of the bridge arm on the primary side; $\delta_{2}$ represents the voltage phase angle at the midpoint of the bridge arm on the secondary side; and $\Delta \delta$ is the phase angle difference between two commutator bridge elements.

\subsection{Photovoltaic Power Generation Device. Photovoltaic} power generation device is a kind of power generation device that converts light energy into electric energy. The photovoltaic power generation in the flexible DC distribution system is mainly composed of photovoltaic panels and Boost links, as shown in Figure 5.

The output voltage and current of photovoltaic panels change with the change of light intensity and cell junction temperature, which has strong nonlinear characteristics, and there is a maximum power output point under a specific working condition. When the light intensity and the cell junction temperature change, the output voltage and output current of the photovoltaic array will also change, so the output power will also change. In order to make full use of solar energy, it is necessary to make the working point of the photovoltaic cell fall to the maximum power point, that is, maximum power point tracking (MPPT) control under the circumstances of light intensity and temperature change [15]. The MPPT algorithm was used to calculate the voltage $\mathrm{V}_{\mathrm{pv}}^{*}$ of the maximum power point under the corresponding lighting and temperature. The control block diagram of the photovoltaic power generation device is shown in Figure 6. $\mathrm{V}_{\mathrm{pv}}$ represents the $\mathrm{DC}$ voltage output by the photovoltaic 

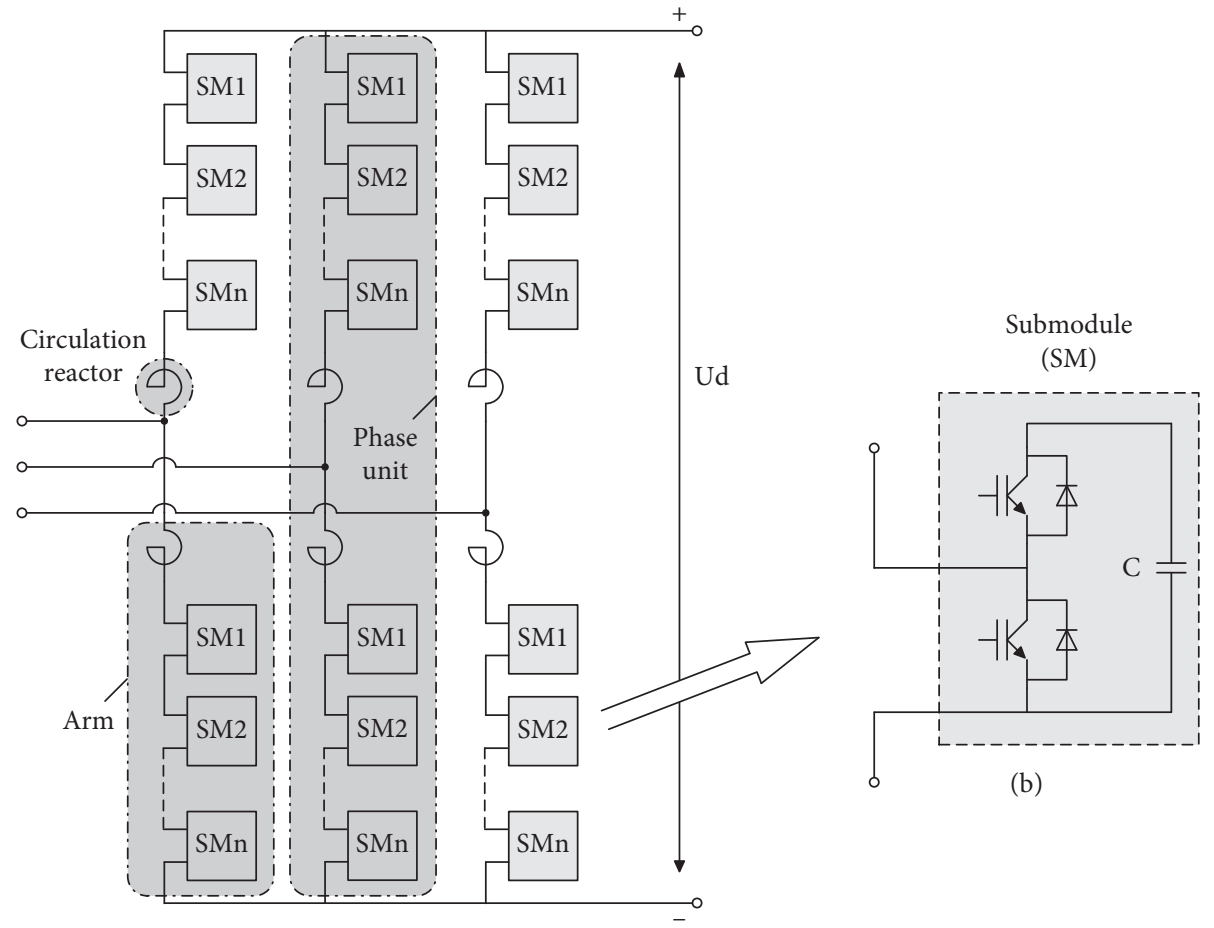

(a)

Figure 1: Main circuit structure of three-phase MMC.

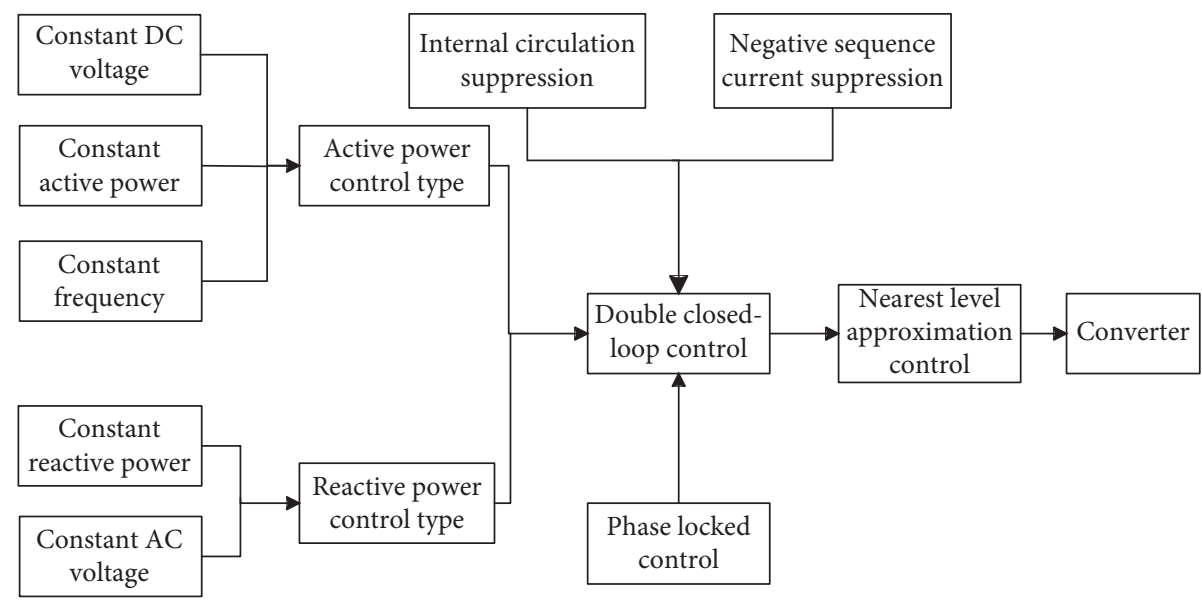

FIGURE 2: Control strategy of modular multilevel converter.

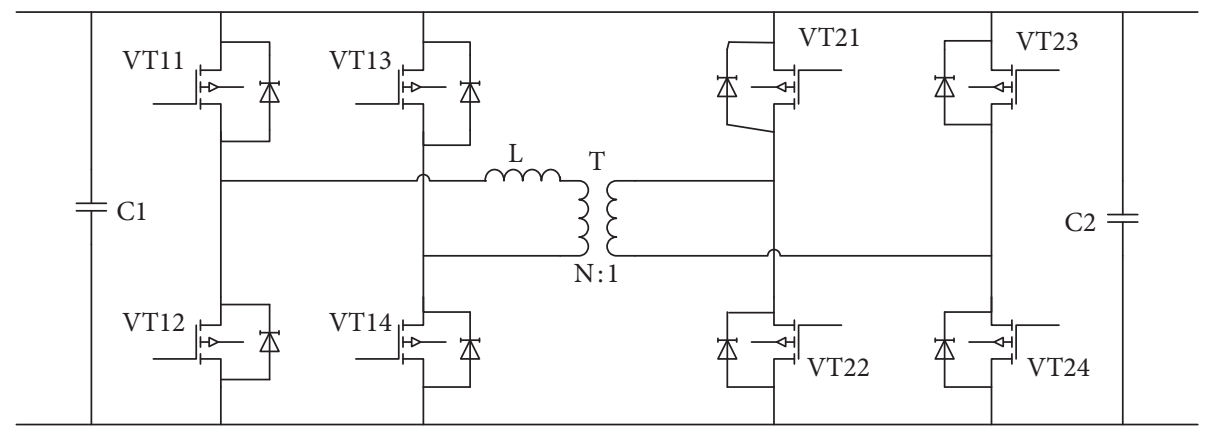

Figure 3: Circuit of dual-active-bridge. 


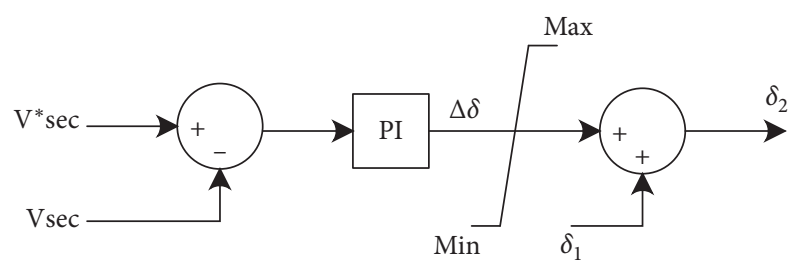

FIgURE 4: Control strategy of dual-active-bridge.

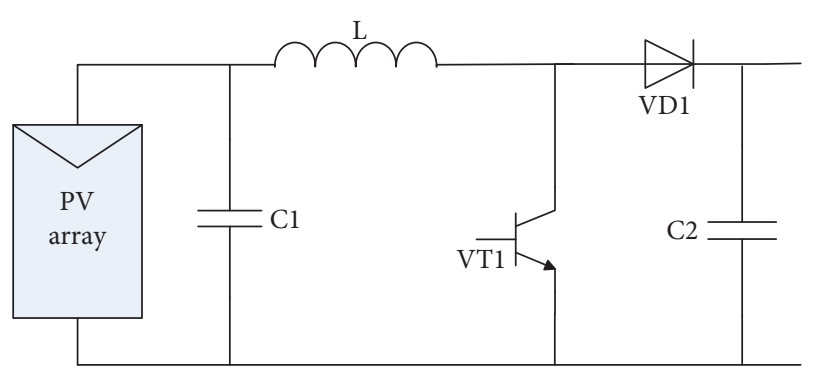

FIGURE 5: PV generation system with Boost converter.

power generation device, and Duty is the on-time DUTY ratio of the controllable device in the Boost circuit [16].

2.4. Wind Power Generation Device. Wind power generation equipment mainly includes wind turbine, gearbox, generator, and converter. The common wind turbines are mainly doubly fed wind turbines and permanent magnet synchronous generators (PMSGs). PMSG has no rotor winding, no excitation power supply, no collector ring, and carbon brush, which simplifies the structure and improves the conversion efficiency. The structure of PMSG in the flexible DC distribution system is shown in Figure 7.

PMSG is a full power converter. Under different wind speeds, the maximum power output speed of the fan is unique. Therefore, the maximum mechanical power can be obtained by adjusting the fan speed; that is, MPPT control is adopted to improve the energy utilization rate of the system. The control strategy of PMSG is shown in Figure 8. Among them, $\omega^{*}$ and $\omega$, respectively, represent the reference value and measured value of wind turbine speed, $i_{s a}, i_{s b}$, and $i_{s c}$, respectively, represent the three-phase current on the generator side, $\mathrm{u}_{\mathrm{sa}}, \mathrm{u}_{\mathrm{sb}}$, and $\mathrm{u}_{\mathrm{sc}}$, respectively, represent the converter three-phase reference voltage, $\omega_{\mathrm{e}}$ represents the angular speed of synchronous motor, $\mathrm{L}_{\mathrm{s}}$ represents the stator inductance, $\Psi_{\mathrm{f}}$ represents the rotor permanent magnet flux, $\mathrm{i}_{\mathrm{sd}}{ }^{*}$ and $\mathrm{i}_{\mathrm{sd}}$ represent $\mathrm{D}$-axis reference current and actual current, respectively, $i_{\mathrm{sq}}{ }^{*}$ and $i_{\mathrm{sq}}$ represent $\mathrm{q}$-axis reference current and actual current, respectively, $\mathrm{u}_{\mathrm{sd}}{ }^{*}$ and $\mathrm{u}_{\mathrm{sd}}$ represent $\mathrm{d}$-axis reference voltage and actual voltage, respectively, and $\mathrm{u}_{\mathrm{sq}}{ }^{*}$ and $\mathrm{u}_{\mathrm{sq}}$ represent $\mathrm{q}$-axis reference voltage and actual voltage, respectively [17].

2.5. Energy Storage of Echelon Utilization Battery. At present, the commonly used energy storage device is lithium battery, which depends on the concentration difference of $\mathrm{Li}+$ to complete the charge and discharge [18]. The architecture model of echelon utilization battery energy storage in the flexible DC distribution system is shown in Figure 9. In the echelon battery energy storage system, the voltage of each battery pack is inconsistent, so the DC/DC converter is needed to increase or decrease the voltage, and then the energy storage system can be connected to the grid. The DC/DC converter in this architecture adopts multichannel interleaving technology, and each battery pack can be equipped with a DC/DC branch to realize the independent charge and discharge, thus reducing the short board effect and safety problems caused by the poor consistency of battery pack in echelon utilization [19]. The working principle of DC/DC converter in the energy storage system is as follows: when discharging, the buck circuit IGBT turns off, the Boost circuit IGBT works, the DC/DC circuit acts as the Boost circuit, and the current flows from the battery to the load or grid; when charging, IGBT of Boost circuit is off, IGBT of buck circuit works, DC/DC circuit is buck circuit, and current flows from power supply to battery.

The operation mode that the energy storage system is connected to grid is constant power control mode [20]. The energy storage converter sends the received output power command to DC/DC converter. The controller of DC/DC converter obtains the SOC of each branch battery pack and sends power command to each DC/DC branch according to the SOC of each branch battery pack. The $\mathrm{DC} / \mathrm{DC}$ branch power system realizes the command tracking accurately through the power closed-loop control [21].

\section{Modeling and Control Strategy of Six- Terminal "Ring" Flexible DC Distribution System}

3.1. Modeling of Flexible DC Distribution System. The sixterminal "ring" flexible DC distribution system is shown in Figure 10 [22-25]. Terminal 1 and terminal 3 are connected to $10 \mathrm{kV}$ AC distribution network, terminal 2 is connected to AC load, terminal 4 is connected to photovoltaic power generation and energy storage device, terminal 5 is connected to $0.38 \mathrm{kV}$ AC microgrid composed of load and synchronous generator, and terminal 6 is connected to DC load, wind power, and energy storage device. Considering the operation characteristics of each terminal, MMC converter is used for terminals 1, 2, 3, and 5 , while DC transformer is used for terminals 4 and 6 . The load at terminal 2 is AC resistive load, and the load at terminal 6 is DC load for the plant. The parameters and operation mode of each terminal are shown in Table 1 [26].

\subsection{Control Strategy of Multiterminal DC Distribution System}

3.2.1. Start-Up Control Strategy. In the start-up process of the flexible direct current system, appropriate start-up control and current limiting measures must be taken to 


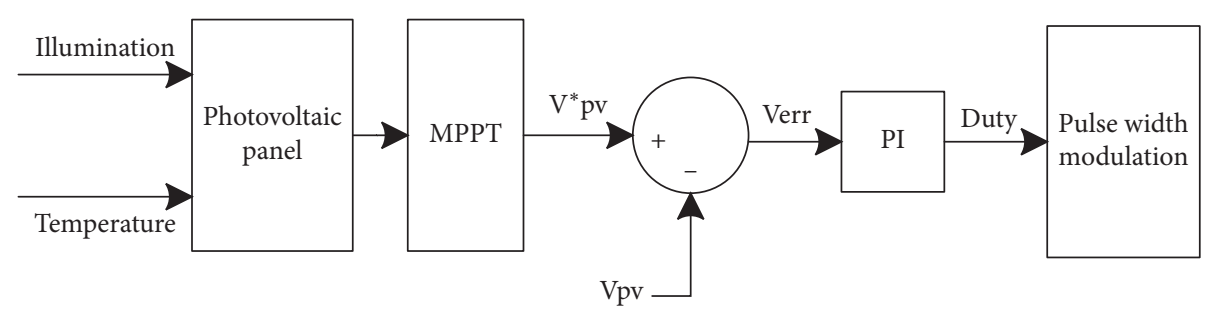

Figure 6: Control strategy diagram of the PV generation system with Boost converter.

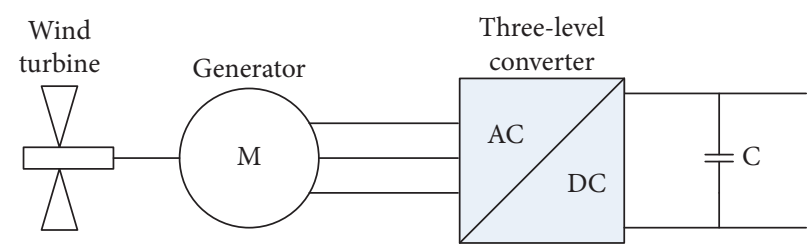

Figure 7: Structure of PMSG-based wind turbine.

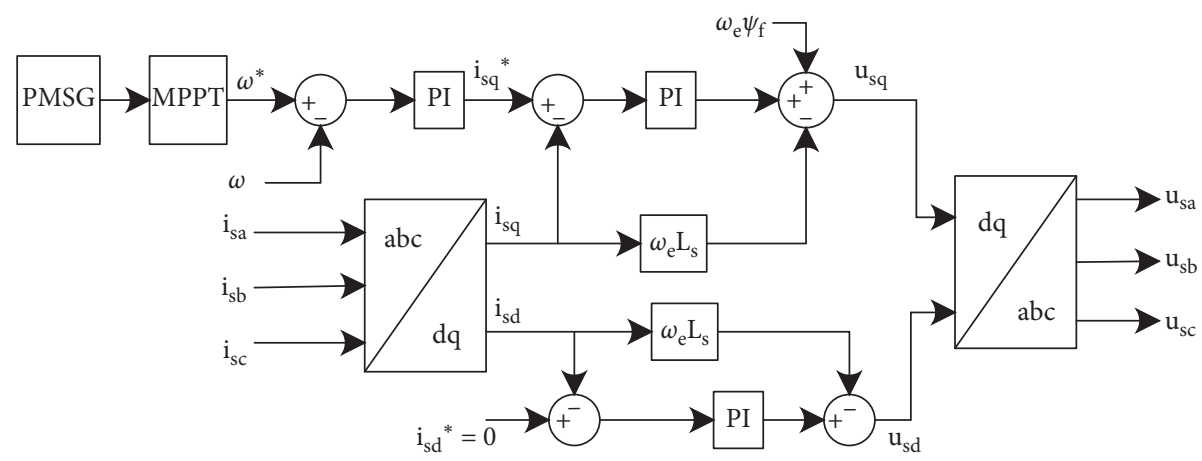

FIgure 8: Control strategy of PMSG.

suppress the phenomenon of overvoltage and overcurrent. The goal of starting control is to make the DC voltage of the flexible DC system rise quickly to the normal working voltage by means of control methods and auxiliary measures but cannot produce the excessive charging current and voltage overshoot phenomenon.

A feasible scheme is to connect the starting resistor in series in the charging loop at start-up, charge the DC capacity through the AC side system voltage, and remove the starting resistor at the end of start-up to reduce the loss, as shown in Figure 11.

The whole starting process of the converter station is divided into two areas: uncontrollable current and controllable current, as shown in Figure 12. In the area where the current is not controllable, the converter station realizes current limit through series starting resistor. In the controlled area, the converter station realizes current limiting by controlling the limiting link of the outer loop controller of the system.

The starting control flow of a six-terminal "ring" DC distribution system is shown in Figure 13.

3.2.2. Multisource Coordinated Control Strategy. Multisource coordination is a kind of power supply method which adopts multiple types of distributed power supply and utilizes the complementary characteristics of different distributed power supplies to improve the output characteristics of distributed power supply [27, 28]. For example, solar energy and wind energy have strong intermittency and fluctuation, respectively, so the output power of solar power generation device and wind power generation device also has intermittency and fluctuation. This kind of distributed power generation device with unstable output will affect the stable and reliable operation of the distribution system. Therefore, photovoltaic power generation and wind power generation devices equipped with an appropriate amount of the energy storage system can improve the output characteristics of distributed power generation, making photovoltaic power generation and wind power generation into controllable and stable power supply.

\section{Simulation Results and Analysis}

Based on the real-time digital simulation platform RTDs, a six-terminal "ring" DC distribution system model is built. RTDS has an MMC valve model based on FPGA, which is conducive to simulate the MMC valve with a large number of switching elements and the internal pressure balancing problem of the analog valve. In this six-terminal model, the 


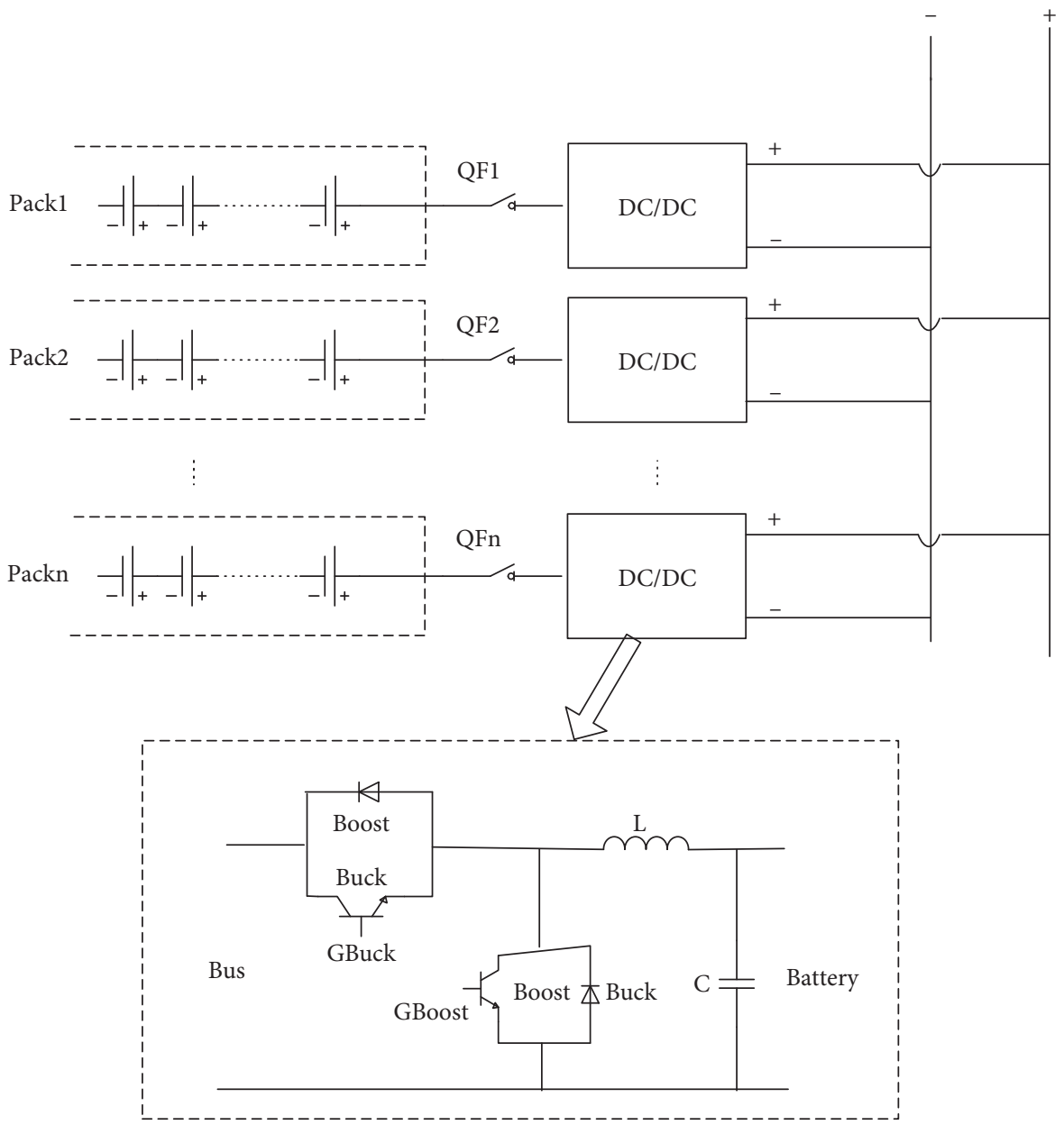

FIgURE 9: Architecture diagram of the echelon utilization battery energy storage model.

1-terminal and 3-terminal converter valves run in FPGAbased hardware, and the other parts run in RTDS.

4.1. The Simulation of Start-Up. When the system starts up, the auxiliary switches at terminal 1, 2, 3, and 5 are closed to charge the MMC of the whole DC distribution network; when the DC voltage reaches 0.73 p.u. (the reference value is $10 \mathrm{kV})$, the converter station at the first end unlocks and continues to charge the DC network. Until the DC voltage reaches 1 p.u., the main switch at the first end is closed and the other ends are unlocked so that the system enters the noload operation stage. During system start-up, the waveform of DC voltage and charging current at terminal 1 of constant DC voltage is shown in Figure 14. According to the simulation waveform, it takes about $40^{\circ} \mathrm{s}$ for terminal 1 voltage to rise from 0 p.u. to 1 p.u., and the maximum charging current peak is 0.04 p.u. (the reference value is $1 \mathrm{kA}$ ).

When the terminal 2 that is constant frequency voltage (VF) terminal is merged into the DC system, the main switch at the terminal 2 is closed and the AC side voltage is raised according to the established slope to realize the grid-connected control of the two-terminal converter station. The simulation waveforms of at terminal 1 and 2 are shown in Figure 15. The simulation results show that the voltage of terminal 1 is basically stable at 1 p.u., and the DC power of terminal 1 is $0 \sim-1$ p.u. (the reference value is $10 \mathrm{MW}$ ). The effective value of the terminal $2 \mathrm{AC}$ voltage varied from 0 to 0.99 p.u. (AC voltage reference value was $10 \mathrm{kV}$ ), and the terminal 2 DC power varied from 0 to 0.94 p.u., which is lasting for $5 \mathrm{~s}$.

4.2. Power Step. Assume that the operation state of the DC distribution network supplied by this double-ended power source is as follows: (1) terminal 1 is the constant voltage terminal; (2) terminal 5 is AC microgrid that includes $3 \mathrm{MW}$ load and $1 \mathrm{MW}$ synchronous generator, which needs to absorb $2 \mathrm{MW}$ active power from the grid; (3) terminal 3 is the constant power terminal, and the output power is $0 \mathrm{MW}$; (4) terminal 4 is the optical storage access terminal, which is set to transmit $3 \mathrm{MW}$ active power to the power grid; (5) terminal 6 is connected to wind power and energy storage device; and (6) terminal 2 is in the no-load operation stage at this time.

4.2.1. Power Step of Converter Valve. Suppose that at this time, the power of terminal 3 which is the constant power terminal will step from $0 \mathrm{MW}$ to $6 \mathrm{MW}$ and terminal 6 


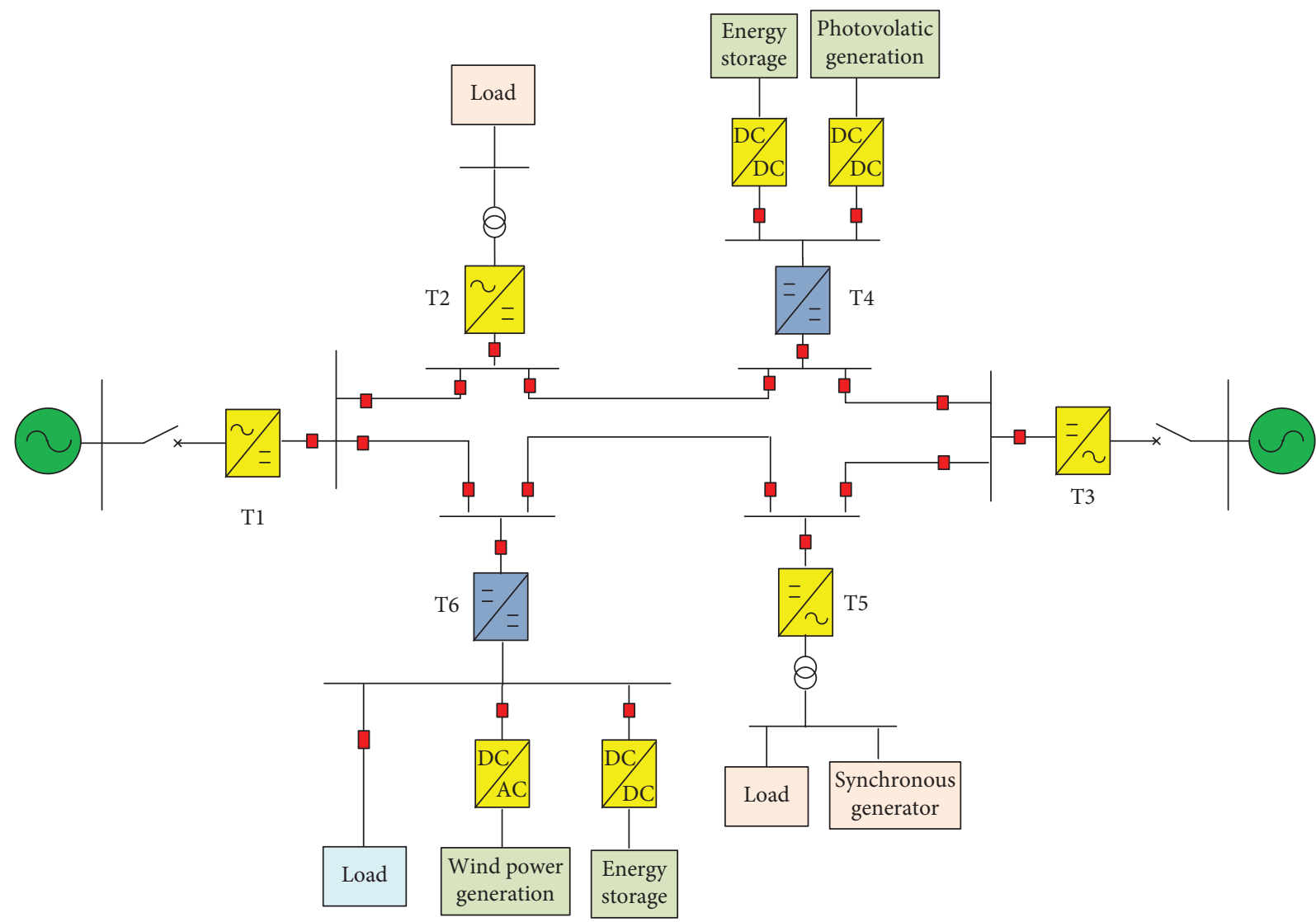

FIGURE 10: The topology of six-terminal ring-shape DC distribution network.

TABLE 1: The parameters and control mode of six-terminal ring-shape DC distribution network.

\begin{tabular}{|c|c|c|c|c|c|}
\hline Terminal & Control mode & Load type & $\begin{array}{c}\text { Voltage } \\
\text { grade }(\mathrm{kV})\end{array}$ & $\begin{array}{c}\text { Capacity } \\
\text { (MW or MVA) }\end{array}$ & Comments \\
\hline 1 & $\begin{array}{l}\text { Constant } \mathrm{DC} \text { voltage and } \\
\text { constant reactive power }\end{array}$ & AC power grid & $\begin{array}{l}\text { AC: } 10 \\
\text { DC: } \pm 10\end{array}$ & Converter: 10 & Connect to infinity power supply \\
\hline 2 & $\begin{array}{l}\text { Constant frequency, } \\
\text { constant AC voltage }\end{array}$ & Load & $\begin{array}{l}\text { AC: } 0.38 \\
\text { DC: } \pm 10\end{array}$ & AC load: 3 & Connected to AC resistive load \\
\hline 3 & $\begin{array}{l}\text { Constant active power, } \\
\text { constant reactive power }\end{array}$ & AC power grid & $\begin{array}{l}\text { AC: } 10 \\
\text { DC: } \pm 10\end{array}$ & Converter: 10 & Connect to infinity power supply \\
\hline 4 & $\begin{array}{l}\text { Constant low voltage DC } \\
\text { voltage or constant power }\end{array}$ & $\begin{array}{l}\text { Photovoltaic power } \\
\text { generation, energy } \\
\text { storage }\end{array}$ & DC: \pm 1.5 & $\begin{array}{l}\text { Photovoltaic power } \\
\text { generation: } 4 \\
\text { Energy storage: } 4\end{array}$ & $\begin{array}{l}\text { Photovoltaic output according to } \\
\text { the light curve }\end{array}$ \\
\hline 5 & $\begin{array}{l}\text { Constant frequency, } \\
\text { constant AC voltage }\end{array}$ & $\begin{array}{c}\text { Synchronous generator, } \\
\text { load }\end{array}$ & $\begin{array}{l}\text { AC: } 0.38 \\
\text { DC: } \pm 10\end{array}$ & $\begin{array}{l}\text { Load: } 3 \\
\text { Synchronous } \\
\text { generator: } 1\end{array}$ & The load is variable \\
\hline 6 & $\begin{array}{l}\text { Constant low voltage DC } \\
\text { voltage or constant power }\end{array}$ & $\begin{array}{l}\text { Wind power generation, } \\
\text { energy storage, load }\end{array}$ & DC: \pm 1.5 & $\begin{array}{c}\text { Wind power } \\
\text { generation: } 3 \\
\text { Energy storage: } 4 \\
\text { Load: } 1\end{array}$ & $\begin{array}{l}\text { The fan control mode is changed } \\
\text { from constant speed to constant } \\
\text { power }\end{array}$ \\
\hline
\end{tabular}

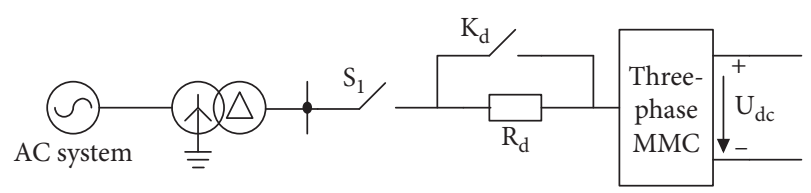

FIGURE 11: Structure of AC side converter station with start-up circuit. transmits $0 \mathrm{MW}$ active power to the power grid. The system simulation waveform is shown in Figure 16. The simulation results show that the DC voltage of the system is stable at 1 p.u. after $3 \mathrm{~s}$. The secondary side voltage (reference value $1.5 \mathrm{kV}$ ) of DC transformers at terminal 4 and terminal 6 is basically stable at 1 p.u. The DC power transmission at each terminal can also be stable in a short time. 


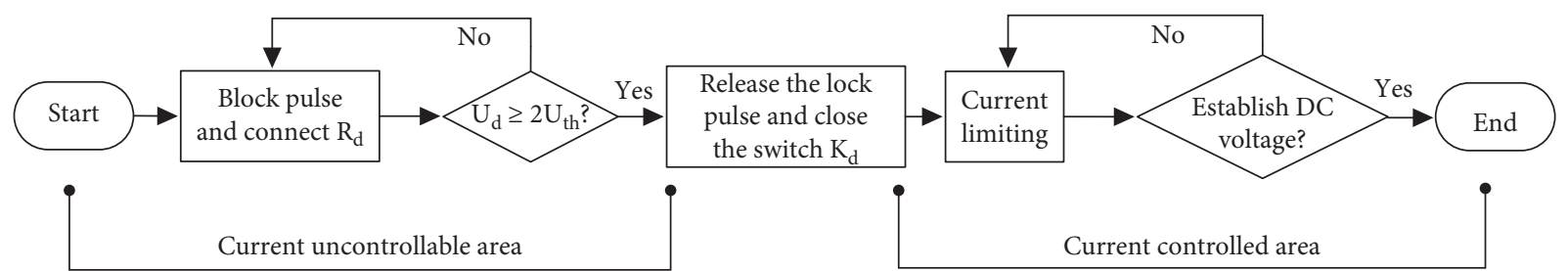

Figure 12: Diagram of start-up control strategy of VSC-HVCD.

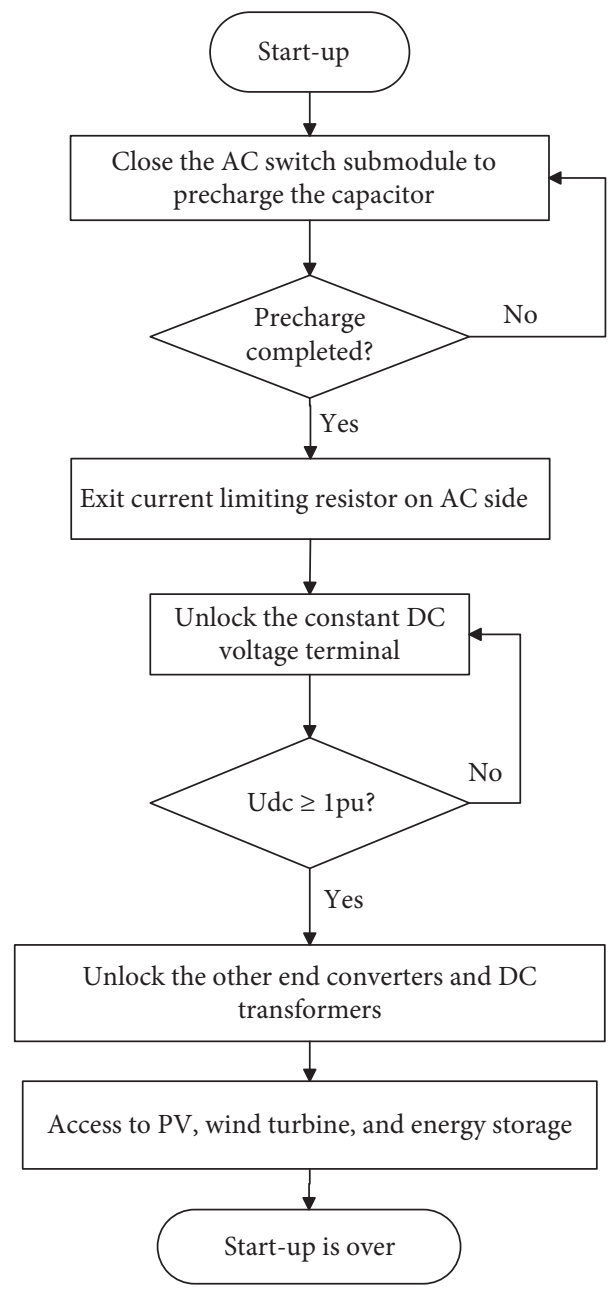

FIgURE 13: Start-up flow chart of the DC distribution system.

4.2.2. Power Step of Load. Based on the above experiments, the load switching experiment is carried out at terminal 5 , and the $3 \mathrm{MW}$ load carried by the terminal 5 is switched off and put into operation within $10 \mathrm{~s}$. The simulation waveform is shown in Figure 17. According to the simulation waveform, when the load switching experiment is carried out at terminal 5, each terminal can quickly return to the stable operation state.

4.3. Multisource Coordinated Control Strategy. When the DC distribution system starts the coordinate control strategy of photovoltaic power generation, energy storage, wind power generation, and energy storage, the terminal 4 and terminal 6 are a stable power source for the whole system. This paper sets the power transmitted to the system at terminal 4 as $3 \mathrm{MW}$ and the temperature as $25^{\circ} \mathrm{C}$. The power output of the photovoltaic device changes with the illumination intensity. The output power waveform of the photovoltaic and energy storage at terminal 4 is shown in Figure 18. It can be seen from Figure 18 that the energy storage device can quickly respond to the power change of the photovoltaic device so that the output power of the terminal 4 is stable.

This paper sets the power transmitted to the system at terminal 6 as $4 \mathrm{MW}$. The output power of the wind power generation device changes with the wind speed and 


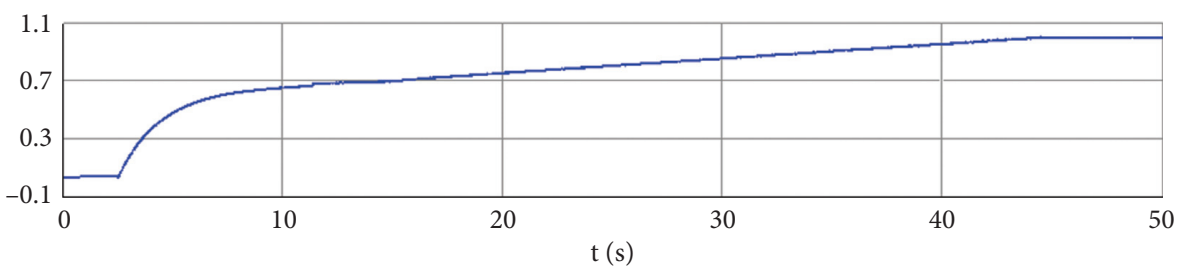

(a)

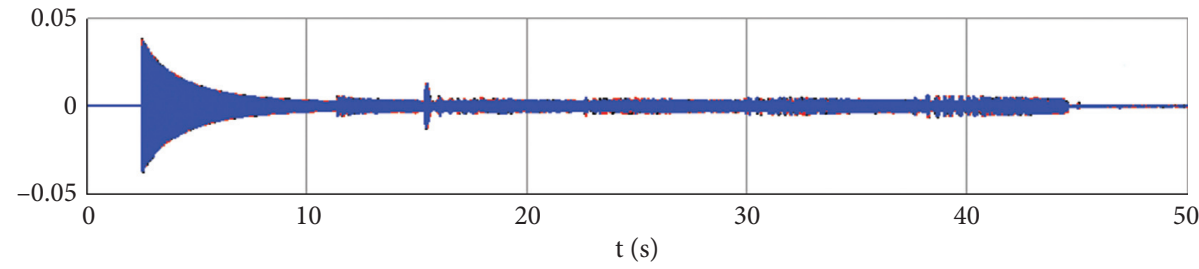

(b)

FIGURE 14: DC voltage and AC charging current waveform of terminal 1 during start-up: (a) DC voltage unit value at terminal 1; (b) AC side charging current unit value at terminal 1.

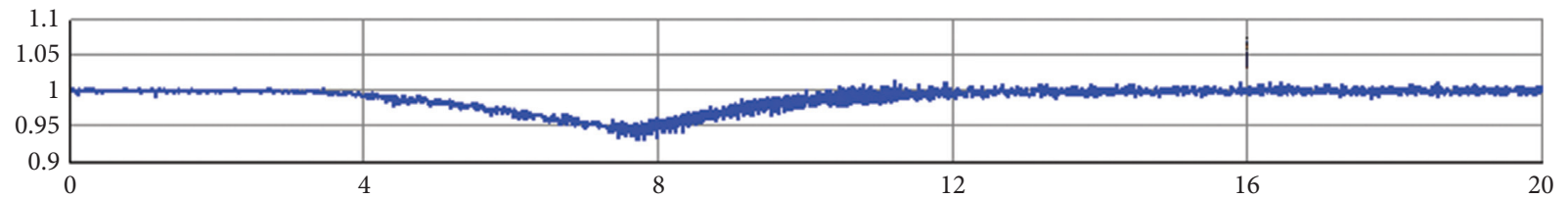

$t(s)$

(a)

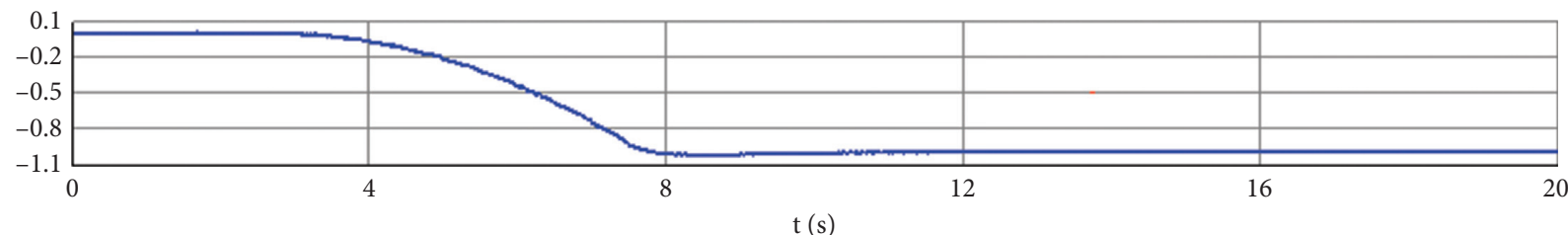

(b)

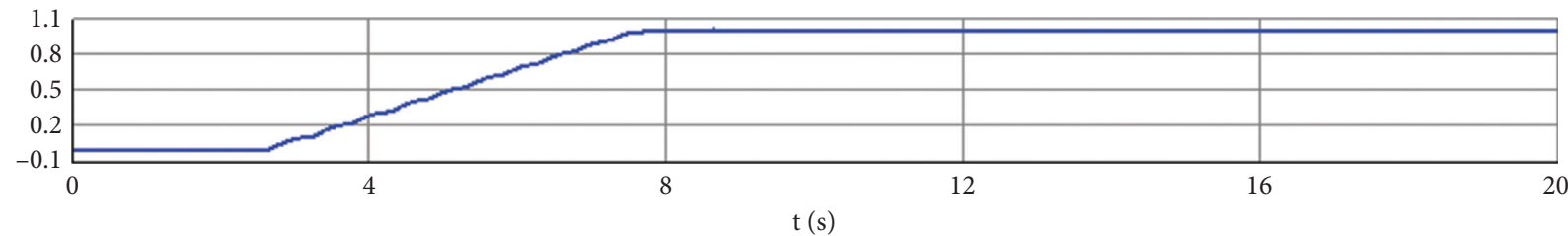

(c)

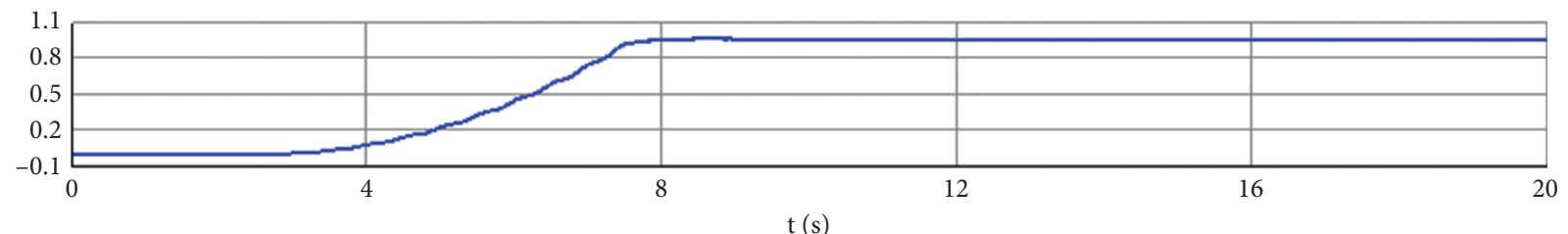

(d)

FIGURE 15: Voltage and power wave form of terminal 1 and terminal 2 when terminal 2 is put into operation: (a) DC voltage unit value at terminal 1; (b) active power unit value at terminal 1; (c) AC voltage RMS unit value at terminal; (d) active power unit value at terminal 2.

direction. The output power waveform of the wind power and energy storage at terminal 6 is shown in Figure 19. As can be seen, the output power of the energy storage device can quickly track the output power of the wind power generation device, thus ensuring that the output power at terminal 6 is constant. 


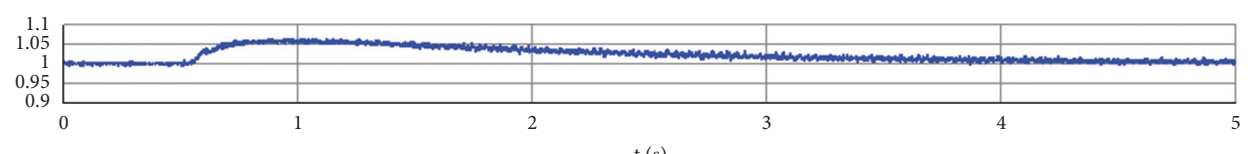

(a)

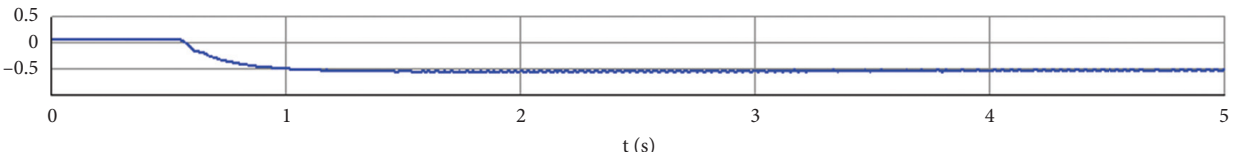

(b)

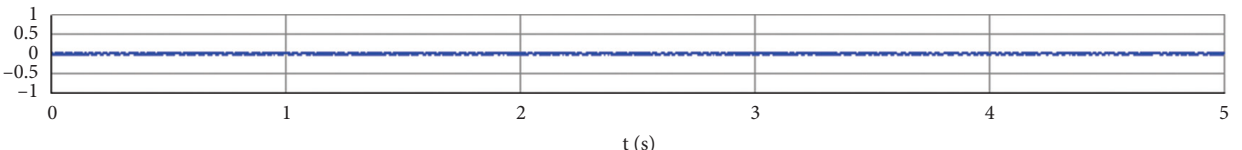

(c)

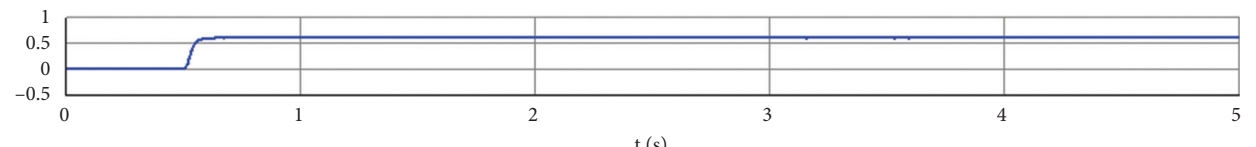

(d)

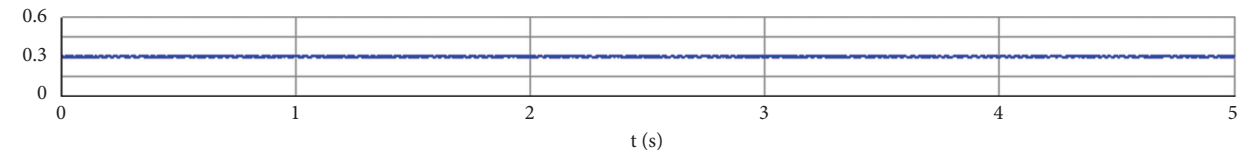

(e)

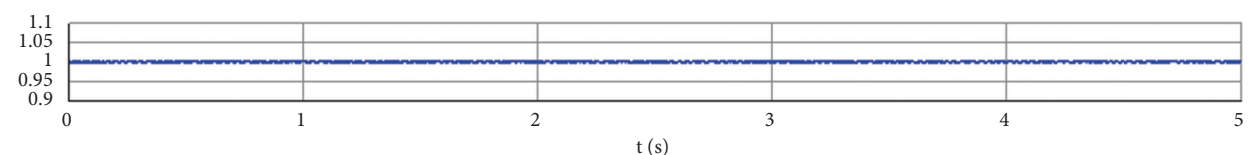

(f)

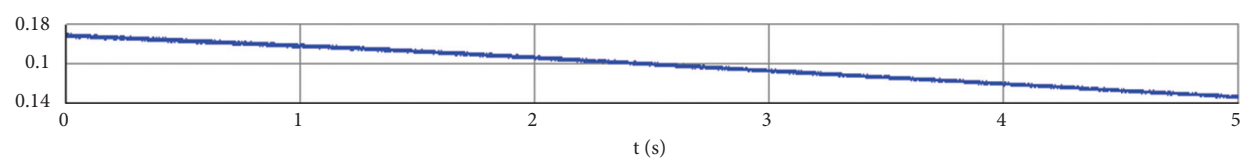

(g)

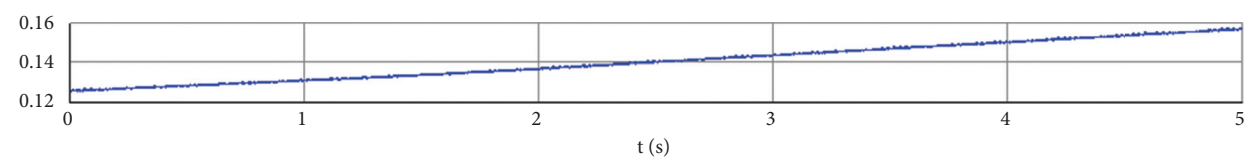

(h)

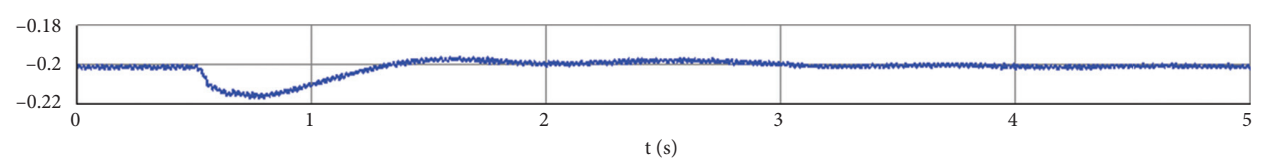

(i)

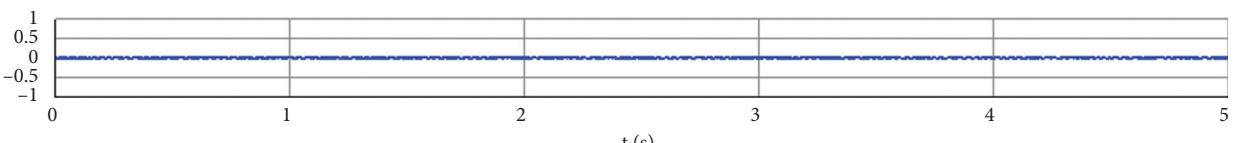

(j)

FIgure 16: Continued. 


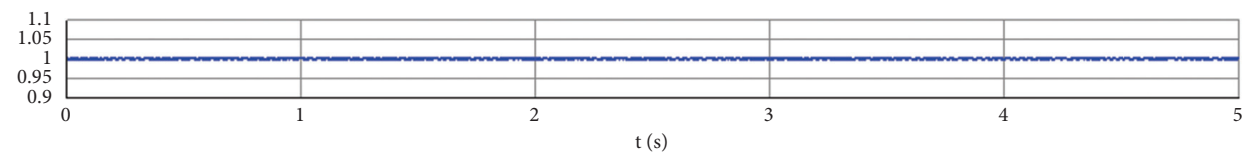

(k)

FIGURE 16: DC voltage and power waveform of the system when power of commutation valve step changes: (a) DC voltage unit value at terminal 1; (b) active power unit value at terminal 1; (c) active power unit value at terminal 2; (d) active power unit value at terminal 3; (e) active power unit value at terminal 4; (f) DC voltage unit value of the DC transformer secondary side at terminal 4; (g) output power unit value of photovoltaic device at terminal 4; (h) output power unit value of energy storage at terminal 4; (i) active power unit value at terminal 5; (j) active power unit value at terminal 6; $(\mathrm{k})$ DC voltage unit value of the DC transformer secondary side at terminal 6.

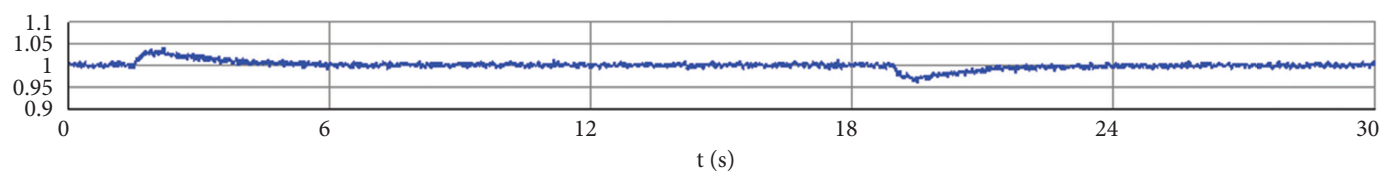

(a)

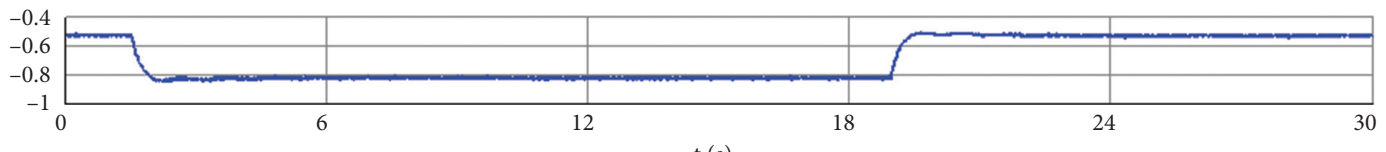

(b)

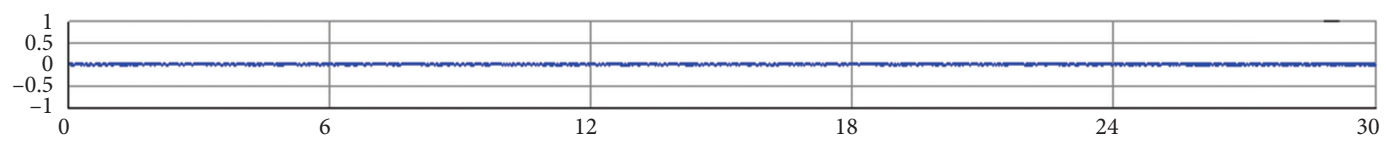

$\mathrm{t}(\mathrm{s})$

(c)

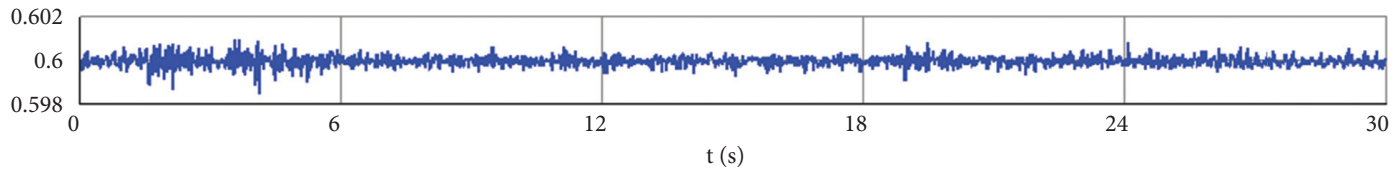

(d)

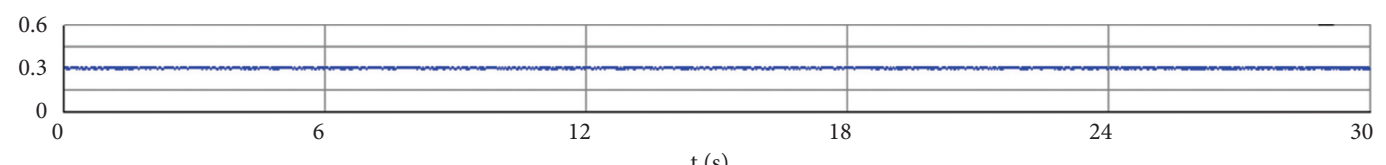

(e)

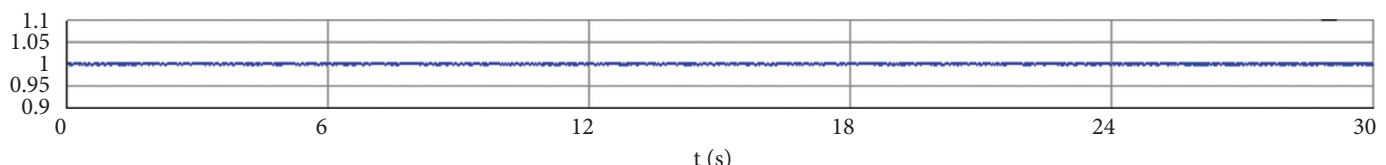

(f)

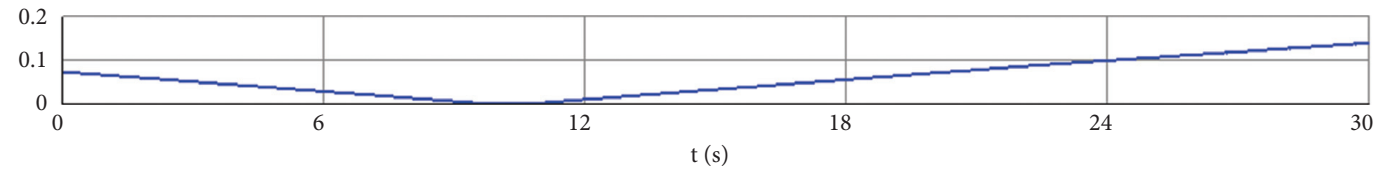

(g)

Figure 17: Continued. 


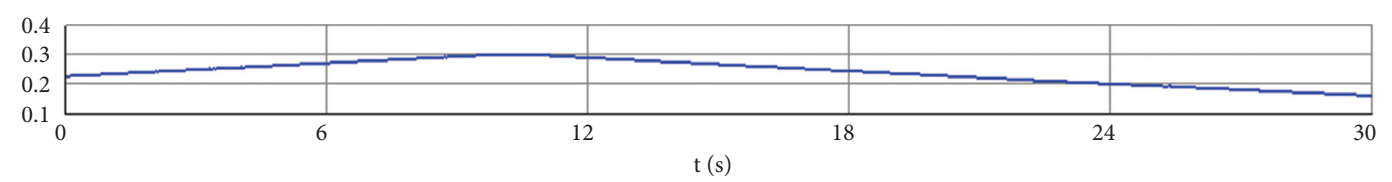

(h)

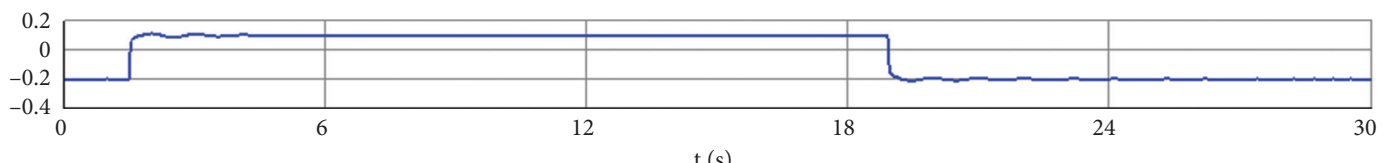

(i)

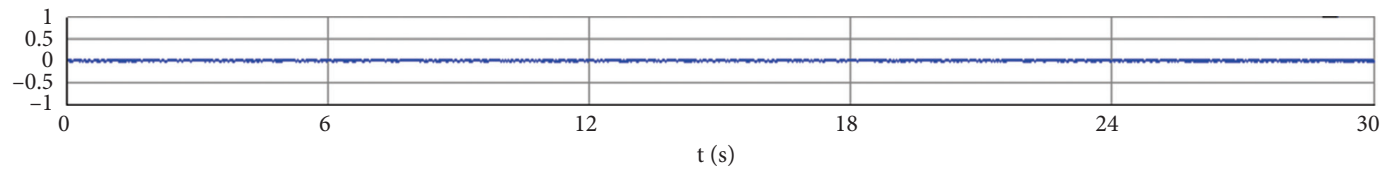

(j)

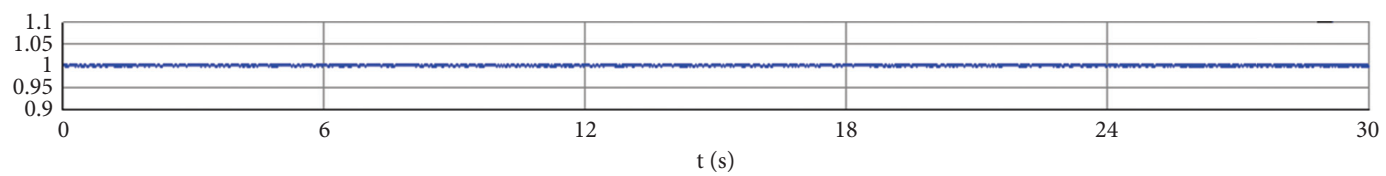

(k)

FIGURE 17: DC voltage and power waveform of the system when load changes at terminal 5: (a) DC voltage unit value at terminal 1; (b) active power unit value at terminal 1; (c) active power unit value at terminal 2; (d) active power unit value at terminal 3; (e) active power unit value at terminal 4; (f) DC voltage unit value of the DC transformer secondary side at terminal 4; (g) Output power unit value of photovoltaic device at terminal 4; (h) Output power unit value of energy storage at terminal 4; (i) Active power unit value at terminal 5; (j) active power unit value at terminal 6; (k) DC voltage unit value of the DC transformer secondary side at terminal 6.

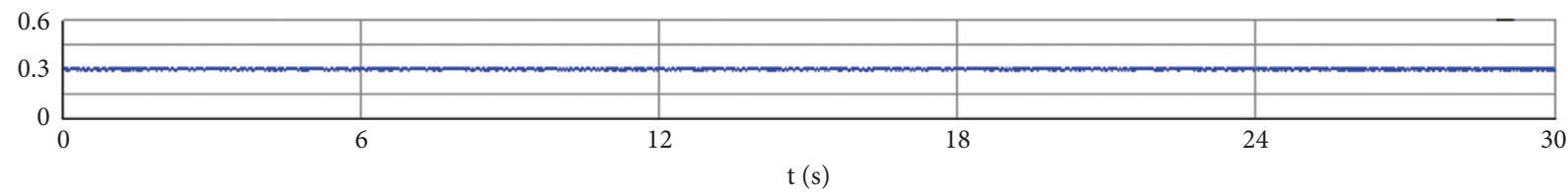

(a)

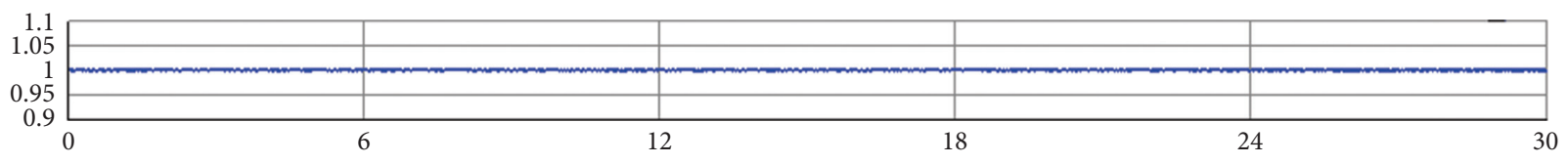

$\mathrm{t}(\mathrm{s})$

(b)

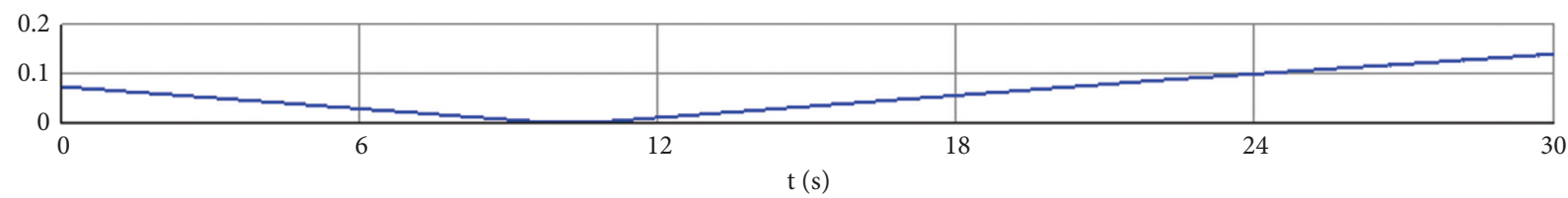

(c)

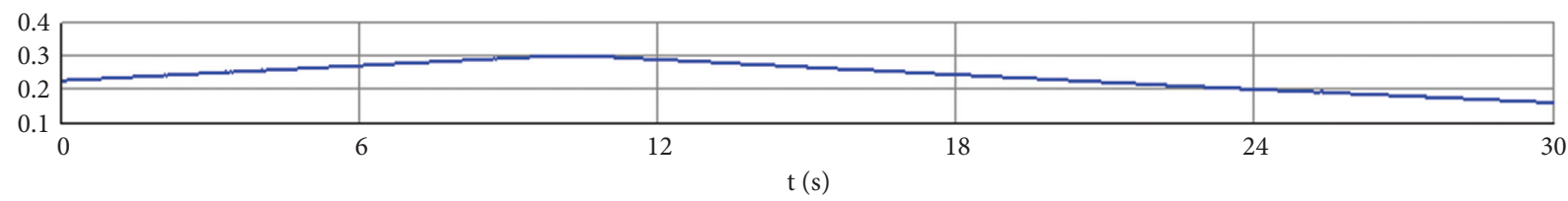

(d)

FIGURE 18: Waveforms of coordinating control of PV generation and energy storage systems at terminal 4: (a) active power unit value at terminal 4; (b) DC voltage unit value of the DC transformer secondary side at terminal 4; (c) output power unit value of photovoltaic device at terminal 4 ; (d) output power unit value of energy storage at terminal 4 . 


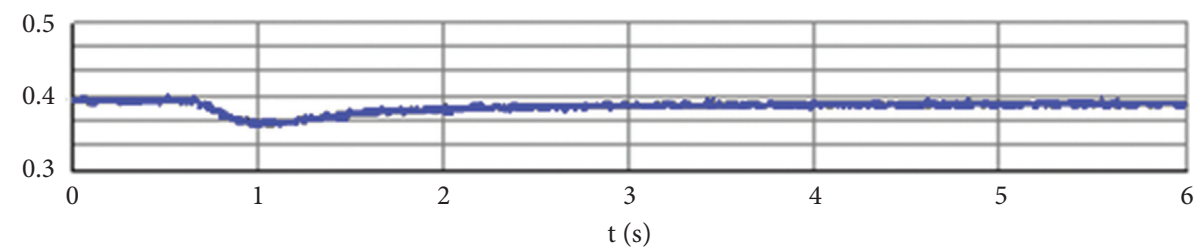

(a)

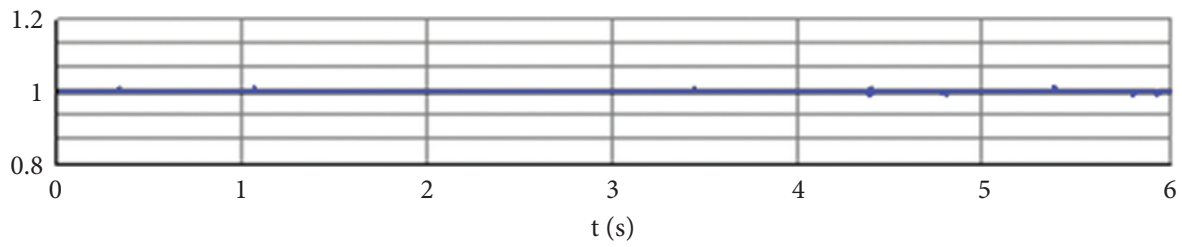

(b)

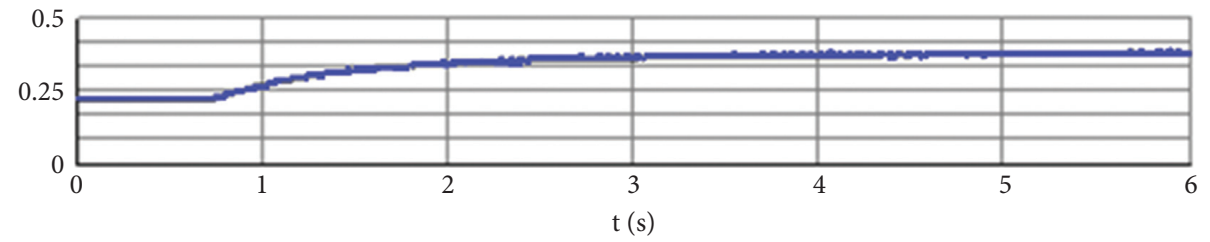

(c)

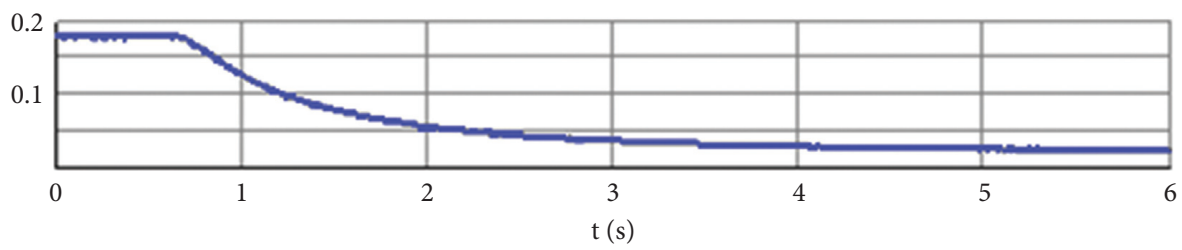

(d)

FIGURE 19: Waveforms of coordinating control of wind power generation and energy storage systems at terminal 6: (a) active power unit value at terminal 6; (b) DC voltage unit value of the DC transformer secondary side at terminal 6; (c) output power unit value of energy storage at terminal 6 ; (d) output power unit value of wind turbine generator at terminal 6.

\section{Conclusion}

The DC distribution system is the key link to ensure power quality, improve operation efficiency, and innovate service content. The models of modular multilevel converter, DC solid-state transformer, photovoltaic power generation device, wind power generation device, and energy storage device established in this paper are consistent with the basic characteristics of the actual device. The start-up strategy can make the multiterminal DC distribution system put into operation quickly and smoothly. Multisource coordinated control strategy can greatly improve the economic benefits of the DC distribution system operation and make the system operate stably. Therefore, the structure and control strategy of each component as well as the system start-up and multisource coordinated control strategy adopted in this paper are correct and effective, which lays a solid foundation for the subsequent control and protection research of the complex DC distribution system. The theoretical and technical problems of planning and design, dispatching control, and relay protection in the DC distribution network need to be further studied.

\section{Data Availability}

The data used to support the findings of this study are included within the article.

\section{Conflicts of Interest}

The authors declare that there are no conflicts of interest.

\section{Acknowledgments}

This work was supported in part by National Natural Science Foundation of China (51807179) and by S\&T Major Project of Inner Mongolia Autonomous Region in China (2020ZD0018).

\section{References}

[1] Q. Song, B. Zhao, W. Liu et al., "An overview of research on smart DC distribution power network," Proceedings of the CSEE, vol. 33, no. 25, pp. 9-19, 2013.

[2] Y. Yu, Y. Jin, Q. Jiang et al., "RT-LAB based modeling and simulation analysis of flexible DC distribution network," 
Power System Protection and Control, vol. 43, no. 19, pp. 125-130, 2015.

[3] G. Tang, Z. He, and H. Pang, "Research, application and development of VSC-HVDC engineering technology," $\mathrm{Au}$ tomation of Electric Power Systems, vol. 37, no. 15, pp. 3-14, 2013.

[4] B. T. Ooi and X. Wang, "Voltage angle lock loop control of the boost type PWM converter for HVDC application," IEEE Transactions on Power Electronics, vol. 5, no. 2, pp. 229-235, 1990.

[5] L. Shu, Z. Yuming, C. Li et al., "Research on control and protection strategy and design scheme of VSC-DC distribution network control and protection system," Distribution \& Utilization, vol. 35, no. 1, pp. 21-27, 2018.

[6] S. Li, Study on Control Strategy and Protection Scheme of VSC Based Distribution Network, North China Electric Power University, Beijing, China, 2016.

[7] W. W. Li, C. Jun, C. Ming et al., "RT-LAB real-time simulation research for multi-terminal VSC-DC power distribution network," Guangdong Electric Power, vol. 28, no. 10, pp. 78-82, 2015.

[8] X. Zheng, Flexible Direct Current Transmission System, Machine Press, Beijing, China, 2013.

[9] G. Li, L. Pengfei, Z. Ming et al., "Development and prospects for HVDC light," Automation of Electric Power Systems, vol. 27, no. 4, pp. 1-5, 2003.

[10] Q. Tu, X. Zheng, W.-Z. Yao et al., "Selecting number of voltage levels for modular multilevel converter based HVDC," Power System Protection and Control, vol. 38, no. 20, pp. 33-38, 2010.

[11] X. Zhai and C. Zhao, "Study of modular multilevel dynamic voltage restorer," Power System Protection and Control, vol. 41, no. 12, pp. 86-91, 2013.

[12] M. Guan and X. Zheng, "Modeling and control of modular multilevel converter based VSC-hvdc system connected to passive networks," Transactions of China Electrotechnical Society, vol. 28, no. 2, pp. 255-263, 2013.

[13] J. Lago and M. Heldwein, "Operation and control-oriented modeling of a power converter for current balancing and stability improvement of DC active distribution networks," IEEE Transactions on Power Electronics, vol. 26, no. 3, pp. 877-885, 2011.

[14] A. Radwan and Y. Mohamed, "Linear active stabilization of converter-dominated DC microgrids," IEEE Transactions on Smart Grid, vol. 3, no. 1, pp. 203-216, 2012.

[15] G. Hsieh, H. Hsieh, C. Tsai et al., "Photovoltaic power-increment-aided incremental-conductance MPPT with twophased tracking," IEEE Transactions on Power Electronics, vol. 28, no. 6, pp. 2895-2911, 2013.

[16] X. Zhou, D. Song, and Y. Ma, "Control strategy of photovoltaic grid-connected inverter," East China Electric Power, vol. 38 , no. 1, pp. 81-83, 2010.

[17] X. Wu, D. Tongzhen, X. Wenjing et al., "Real time simulation of grid side converter in wind power generation system based on RT-LAB," Southern Power System Technology, vol. 47, no. 10, pp. 17-19, 2013.

[18] C. Wei, M. Benosman, and T. Kim, "Online parameter identification for state of power prediction of lithium-ion batteries in electric vehicles using extremum seeking," International Journal of Control, Automation and Systems, vol. 17, no. 11, pp. 2906-2916, 2019.

[19] F. Li, "Cascade utilization battery energy storage system Architecture and control strategy," Electrical Appliances and Energy Efficiency Management Technology, vol. 4, pp. 81-84, 2021.
[20] H. Liu and Y. Lei, "Dual-passivity-based control strategy of energy storage converter under microgrid operation mode switching," Electric Power, 2021, https://kns.cnki.net/kcms/ detail/11.3265.TM.20210513.1510.008.html.

[21] Y. Li, P. Peng, and B. Liu, "Research on the integration and control strategy of echelon use battery energy storage system," Power Electronics, vol. 55, no. 3, pp. 13-16, 2021.

[22] G. Jiang, Z. Li, H. Yang et al., "Research review on topological structure of flexible HVDC system," Power System Protection and Control, vol. 43, no. 15, pp. 145-154, 2015.

[23] B. Zhao, Y. Wang, Y. Zhao et al., "Energy internet based on flexible medium-voltage DC distribution," Proceedings of the CSEE, vol. 35, no. 19, pp. 3391-3403, 2015.

[24] G. Liu, Y. Zhao, Z. Yuan et al., "Study on demonstration project technical scheme of VSCDC distribution system in Shenzhen," Southern Power System Technology, vol. 10, no. 4, pp. 1-7, 2016.

[25] B. Zhao, Q. Song, W. Liu et al., "High-frequency-link DC solid state transformers for flexible DC distribution," Proceedings of the CSEE, vol. 34, no. 25, pp. 4295-4303, 2014.

[26] C. Wei, Z. Shen, D. Xiao, L. Wang, X. Bai, and H. Chen, “An optimal scheduling strategy for peer-to-peer trading in interconnected microgrids based on $\mathrm{RO}$ and nash bargaining," Applied Energy, vol. 275, 2021.

[27] M. Mou, D. Lin, Y. Zhou, W. Zheng, J. Ruan, and D. Ke, “An optimal allocation strategy for multi-energy networks based on double-layer non-dominated sorting genetic algorithms," Complexity, vol. 2019, Article ID 5367403, 11 pages, 2019.

[28] M. Mou, Y. Zhou, W. Zheng, D. Ke, Z. Zhang, and D. Lin, "Real-time optimal control strategy for multi-energy complementary microgrid system based on double-layer nondominated sorting genetic algorithm," Complexity, vol. 2020, Article ID 8852186, 12 pages, 2020. 